\title{
Kollektív igényérvényesítés Európa egyes államaiban
}

\author{
kollektív igényérvényesités - közérdek - közérdekü perlés - \\ csoportos perlés - fogyasztóvédelem
}

Kollektív igényérvényesítési mechanizmussal, a csoportos és a reprezentatív típusok különböző fajtáival ${ }^{1}$ Európa legtöbb országában találkozhatunk (kivételek például Svájc ${ }^{2}$ vagy Csehország, ahol a tömeges jogsértések kezelésére szolgáló általános kollektív eljárásokat nem vezettek be). ${ }^{3} \mathrm{~A}$ kollektív igényérvényesítési rendszerek számos jogpolitikai célt szolgálhatnak, melyek közül legjelentősebbnek a joghoz jutás elösegítését, a költségek csökkentését, az igazságügy müködésének gazdaságosságát, a felek közötti tényleges egyenlőség biztosítását, az eltérő döntések elkerülését, valamint a gazdasági szereplők viselkedésmintáinak javítását tekinthetjük. ${ }^{4} \mathrm{~A}$ tömeges szinten nyújtott szolgáltatások elkerülhetővé teszik a bírósági eljárások megtöbbszöröződését, ezért egyre fontosabbá válnak. ${ }^{5}$ A jogalkotási megoldások sokszínüek, de alapvetően két irányvonal jellemző, ${ }^{6}$ illetve ezek kombináció-

* Dr. Jagusztin Tamás, Pest Megyei Főügyészség, osztályvezető ügyész; PhD-hallgató, DE Marton Géza Állam- és Jogtudományi Doktori Iskola, Debrecen, jagusztin.tamas@gmail.com. A tanulmány az Igazságügyi Minisztérium a jogászképzés színvonalának emelését célzó programjai keretében készült.

1 BerHG, Roger van den: Private Enforcement of Europiean Competition Law and the Persisting Collective Action Problem. Maastricht Journal of Europiean Competition Law, 2013/1, 14.

2 Kollektiver Rechtsschutz in der Schweiz - Bestandesaufnahme und Handlungsmöglichkeiten Bericht des Bundesrates, 2013, https://www.bj.admin.ch/dam/data/bj/aktuell/news/2013/2013-07-03/ber-br-d.pdf, 14 (2018. 03. 20.).

3 HamuĹÁко Á, Klára: Empirical Reports, Czech Republic. In: State of Collective Redress in the EU in the Context of the Implementation of the Commission Recommendation (2013/396/EU). British Institute of International and Comparative Law, 2017, 150.

${ }^{4}$ GibBons, S. M. C.: Group Litigation, Class actions and Collective Redress: An Anniversary Reappraisal of Lord Woolf's Three Objectives. In: Dwyer, D. (ed.): The Civil Procedure Rules Ten Years On. Oxford University Press, Oxford-New York, 2009, 129; AndREws, Neil: English Civil Procedure, Fundamentals of the New Civil Justice System. Oxford University Press, Oxford-New York, 2003, 974; UdvarY Sándor: The Advantages and Disadvantages of Class Action. Iustum Aequum Salutare, 2013/1, 68; HARSÁGI Viktória: A kollektív igényérvényesítés fejlesztési lehetöségei. Acta Univ. Sapientiae Legal Studies, 2015/2, 218; HARSÁGI Viktória: A modellválasztás dilemmái a kollektív igényérvényesítés hazai szabályozásánál. Eljárásjogi Szemle, 2016/1, 24.

5 Zuckerman, Adrian: Zuckerman on Civil Procedure. Principles of Practice. Sweet\&Maxwell, London, 2013, 655.

6 A nemzetközi és a hazai kutatásokban többféle csoportosítással találkozhatunk. A szerző által alkalmazott két irány nagyvonalú meghatározásnak tekinthető, de a keresettípusok további absztraháló csoportosítása, a különböző alaptípusok tartalma és elnevezése külön tanulmány témája lehetne, és jelen esetben a gya- 
in alapuló rendszerek jöttek létre. Az egyik vonalat azok a típusok alkotják, amelyek a társadalom vagy egy - személyében sok esetben nem azonosított - közösség kollektív érdekei (közérdek) ${ }^{7}$ védelme iránt indíthatók. Az ilyen igényérvényesítésekre általában csak a jogalkotó által kijelölt állami szervek, vagy ezen érdekek védelmére hivatott egyéb szervezetek jogosultak, és meghatározott jogok védelme iránt. ${ }^{8} \mathrm{~A}$ tag hozzájárulása a per megindításához nem szükséges, de nem is léphet ki a csoportból. ${ }^{9} \mathrm{~A}$ kollektív mechanizmusok másik típusa az egyének csoportjának homogén igényei érvényesítését segítik elő az összevont fellépés előnyeinek kihasználásával (társult perlés). Ezekben az esetekben a jogosultak maguk döntenek a részvételröl. Az opt-in rendszerben a csoporttagoknak kifejezett hozzájárulásukat kell adniuk a csoportperhez, hogy az kiterjedjen rájuk. Az opt-out rendszereket a meghatalmazás nélküli képviseleti jog jellemzi: a per az összes csoporttagra kiterjed, kivéve azokat, akik a csoportból kifejezett nyilatkozattal kiléptek (feltéve, hogy a kilépés megengedett). ${ }^{10} \mathrm{~A}$ csoporttagok igényeit egy személy (szervezet) képviseli, aki az összes felperes érdekében szólal fel, ${ }^{11}$ és egy eljárásban bírálják el az igényeket. ${ }^{12}$ Meg kell jegyezni, hogy a két irányvonal közötti különbségtétel természetesen viszonylagos, a csoportos igényérvényesítés tág értelemben a közérdekű pereket is átfogja. ${ }^{13}$

Az új hazai polgári perrendtartás, ${ }^{14}$ követve az Európában létező megoldásokat, két kollektív perlési formát vezetett be magánjogunk rendszerébe: a közérdekből indított perlés és a társult per jogintézményeit. A közérdekböl indított perek területén - a szakértöi javaslatot ${ }^{15}$ követve - a közös szabályok kidolgozása történt meg. ${ }^{16}$ A társult per létjogosultságát igazolja, hogy a csoport erejének egyesítése növeli a

korlati megoldások összehasonlító elemzése a célunk. E tekintetben csak jelzés szintjén említjük, hogy például az Európai Bizottság külön kutatást rendelt meg ebben a témában. Az ún. Ashurst-tanulmány például a csoportos igényérvényesítés (group litigation) öt különböző típusát különböztette meg. WAELBROECK, DenisSLATER, Donald-EVEn-Shoshan, Gil: Study on the conditions of claims for damages in case of infringement of EC competition rules. http://ec.europa.eu/competition/antitrust/actionsdamages/comparative_report_clean_ en.pdf (2018. 03. 20.).

7 JóJÁRT Eszter: A közérdekböl indított per. In: Petrik Ferenc (szerk.): Polgári eljárásjog Kommentár a gyakorlat számára. Harmadik kiadás, Budapest, HVG-ORAC, 2017, 1209.

8 KECSKÉs László-WALLACHER Lajos: A csoportos jogérvényesítés lehetséges formái választottbíráskodás keretében a magyar jogban. In: Kecskés László-Lukács Józsefné (szerk.): Választottbírók Könyve. Budapest, HVG-ORAC, 2012, 283.

9 NAGY Csongor István: A csoportos igényérvényesítés összehasonlító jogi modelljei - I. rész. Az amerikai class action. Külgazdaság - Jogi Melléklet, 2010/9-10, 94.

10 NAGY Csongor István: Javaslat a csoportper honi szabályozására az új Polgári Perrendtartás kodifikációjának apropóján. Magyar Jog, 2014/4, 213.

11 Hodges, Christopher: Multi-party Actions. Oxford University Press, Oxford-New York, 2001, 73.

12 Hodges, Christopher: The Reform of Class and Representative Actions in European Legal Systems. Hart Publishing, Oxford, 2008, 2.

13 NAGY Csongor István: A csoportos igényérvényesítés gazdaságtana és lehetőségei a magyar jogban. Jogtudományi Közlöny, 2011/3, 163.

14 A polgári perrendtartásról szóló 2016. évi CXXX. törvény. Hatályos 2018. január 1-jétől.

15 HARSÁGI Viktória: Kollektív igényérvényesítés - Általános indokolás a kollektív igényérvényesítéshez. In: Varga István-Éless Tamás (szerk.): Szakértői javaslat az új polgári perrendtartás kodifikációjára. Magyar Közlönykiadó-HVG-ORAC, Budapest, 2016, 753-754.

16 HARSÁGı Viktória: A közérdekből indított per. In: Varga István (szerk.): A Polgári Perrendtartás és a kapcsolódó jogszabályok kommentárja II/III. Budapest, HVG-ORAC, 2018, 2005. 
fegyveregyenlőséget, és segítheti helyrebillenteni az erőforrások egyenlőtlenségét, a hatalmi egyensúlytalanságokat. ${ }^{17}$

A hazai megoldást övező európai kontextus egy szeletének bemutatása, az eddigi tapasztalatok összegzése elősegítheti ezeknek a jogintézményeknek a mélyebb megismerését. Ezért ebben a tanulmányban öt ország kollektív rendszerének struktúráját, az igényérvényesítések gyakorlatát, valamint az azokat elősegítő és gátló tényezőket szeretnénk bemutatni. Természetesen bármelyik kollektív igényérvényesítési mechanizmussal rendelkező ország jogrendszere elemzésre érdemes lenne, de terjedelmi okokból szükséges volt e tanulmányban olyan típusok kiválasztása, amelyek a kollektív érdekek védelmére egymástól érdemben eltérő megoldásokat alakítottak ki. A választásnak az is szempontja volt, hogy olyan jogrendszerek kerüljenek bemutatásra, amelyek a témával foglalkozó - föleg az angolszász és a Benelux államokban, valamint Németországban lévő mechanizmusokra koncentráló - szakirodalomban kisebb hangsúllyal szerepelnek. Az országok sorrendjének megválasztása is tudatos. Ausztriában nincs társult perlési mechanizmus, viszont ezt pótló megoldást alakított ki a joggyakorlat. Az olasz jogalkotó ezzel szemben kizárólag a társult perlés alapját kívánta megteremteni, amelyet az ügyész amicus curiae jellegủ részvételével egészített ki a társadalmi érdekek érvényesülése érdekében. A francia jogba, amely a közérdekủ igények érvényesítésében széles körü hagyományokkal rendelkezik, 2014-ben új jogintézményként vezették be a társult perlés lehetőségét. A portugál jog a közérdek védelmére helyezi a hangsúlyt, de sajátos rendszert alakított ki, a perindításra bármely állampolgár vagy akár külföldi személy is jogosult. A litván jogrend pedig tisztán a közérdek védelmében való fellépést teszi lehetővé a jogszabályban meghatározott jogosultak számára.

A tanulmány záró részében a bemutatott megoldások összehasonlításával célunk annak elemzése, hogy a hasonló problémákra adott eltérő megoldások közül melyek, milyen hatékonysággal töltik be a kollektív érdekek védelmében feladatukat, valamint annak a kérdésnek a körbejárása, hogy kimutathatók-e közös pontok a hatékonyságot elösegítő vagy épp akadályozó körülmények között.

\section{Ausztria}

\subsection{Kollektív igényérvényesítési lehetőségek}

Ausztriában nincs kifejezetten az egyéni igények érvényesítését elősegítő csoportos mechanizmus, azonban vannak egyéb eljárásjogi lehetőségek. ${ }^{18} \mathrm{Az}$ osztrák polgári perrendtartás (Zivilprozessordnung - ZPO) ${ }^{19}$ a felperesek pertársaságát és az ügyek egyesítését teszi lehetővé. Az osztrák fogyasztóvédelmi törvény

17 HARSÁGI (2015): i. m., 218.

18 KoDEK, Georg: Empirical Reports, Austria. In: State of Collective Redress in the EU in the Context of the Implementation of the Commission Recommendation (2013/396/EU). British Institute of International and Comparative Law, 2017, 120.

19 RGBI. Nr. 113/1895 11. §, 187. §. 
(Konsumentenschutzgesetz - KSchG) ${ }^{20} 1979$. október 1. napján történt hatálybalépésével a fogyasztóvédelmi szervezetek lehetőséget kaptak képviseleti (reprezentatív) kereset benyújtására. A jogsértés megszüntetésére irányuló eljárás tekintetében a KSchG különbséget tesz - hasonlóan a német jogi szabályozáshoz - a tisztességtelen szerződési feltételek miatti fellépés, valamint a fogyasztói jogokat sértő gyakorlatok, illetve a 2009/22/EK irányelv ${ }^{21}$ mellékletében felsorolt irányelvek megsértése miatti fellépés között. A rendelkezésre álló két eljárás közül a tisztességtelen feltételek alkalmazása miatti eljárást sokkal gyakrabban indítanak, mint a fogyasztók jogainak megsértése miatt. Mindkettő célja a jogsértő helyzet megszüntetése, azonban egyik eljárás sem irányulhat a fogyasztókat ért egyedi hátrányok reparálására, a károk megtérítésére. ${ }^{22}$

Az osztrák jogrendszerben más jogszabályok is tartalmaznak fogyasztói jogérvényesítési lehetőségeket, melyek az arra feljogosított szervezeteket illetik meg. Hasonlóképpen a tisztességtelen versenyröl szóló törvény (Gesetz gegen Unlauteren Wettbewerb - UWG), ${ }^{23}$ a gyógyszeriparról szóló törvény (Arzneimittelgesetz) ${ }^{24}$ és a légügyi törvény (Luftfahrtgesetz) ${ }^{25}$ is tartalmaz ilyen felhatalmazásokat. A hírközlési ágazatban elkövetett jogsértések miatt a törvény alapján (Telekommunikationsgesetz - TKG) ${ }^{26}$ egy további - generális és speciális prevenciót szolgáló - jogkövetkezmény is alkalmazható. Ez az ún. „nyereséglefölözés”, amely ritkán fordul elö. ${ }^{27}$ Ekkor a trösztellenes bíróság (Kartellgericht) határozza meg, hogy a jogosultat mekkora rész illeti meg a jogsértő vállalkozás nyereségéből. Az összeg nagysága az éves árbevétel nagyságától függ, melynek $10 \%$-áig terjedhet a „lefölözés” összege. ${ }^{28}$ Ezek az eljárások a fogyasztók kollektív érdekeit védik az egyedi igényektől elválasztva, alapvetően ezek is közérdekű jellegüek.

Ausztriában a fogyasztók széles körét érintő jogsértések megszüntetése iránti eljárásokat elsősorban arra használják, hogy az igények jogalapját megállapítsák. Például ha a bíróság egy általános szerződéses feltétel kikötését semmisnek nyilvánítja, a fogyasztó már olyan helyzetbe kerülhet, hogy igényelheti a jogsértő rendelkezés alapján korábban általa megfizetett összeget. Lehetőség van arra is, hogy a sérelmet szenvedett fogyasztó egy fogyasztóvédelmi szervezetet bízzon meg a jogsértés miatti fellépésre. A megoldás elönye, hogy kiküszöbölhető az egyéni igényérvényesítés azon korlátja, miszerint az egyéni fogyasztói követelés összege nem haladja meg az osztrák Legfelsőbb Bíróság (Oberster Gerichtshof) felülvizsgálati

20 BGBI Nr. 140/1979, 28-30. §.

21 A fogyasztói érdekek védelme érdekében a jogsértés megszüntetésére irányuló eljárásokról szóló, 1998. május 19-i 98/27/EK európai parlamenti és tanácsi irányelv, melyet több módosítás után a 2009/22/EK európai parlamenti és tanácsi irányelv kodifikált.

22 KARTSTEN, Jens: Study on the application of Directive 2009/22/EC on injunctions for the protection of consumers' interests (former Directive 98/27/EC), Specific Contract N 17.010403/11/596569, Final Report, 2011.

23 BGBI Nr. 448/1984, 113. §.

24 BGBI Nr. 185/1983, 85/A. §.

BGBI Nr. 253/1957, 115/A. §.

BGBI 70/2003, 111. §.

27 KoDEK, Georg: Atomised Losses in Tort Law: Conceptual Difficulties and Modern Developments. Journal of European Tort Law, 2015, 109.

28 KaRTSTEN: i. m., 35. 
eljárásának a ZPO 502. §-ában elöírt minimumértékét (5000 euró). Az ún. „tesztügyben" hozott döntésnek azonban nincs kötöereje a többi azonos vagy hasonló jogi alapon nyugvó eset tekintetében, mégis a hasonló jellegü követelések tekintetében a fellépés mérlegeléséhez, illetve a bírói döntéshez irányadó lesz. Ha a vállalkozás a meghozott döntés ellenére nem hajlandó a teljesítésre, a fogyasztónak magának kell pert indítania. Viszont ebben az esetben az alapperben megállapított jogsértés alapján már nagyobb eséllyel tudja érvényesíteni követelését a vállalkozással szemben. Továbbá a fogyasztóvédelmi szervezet is elősegítheti a fogyasztói érdekérvényesítést „tesztügyek” megindításával. ${ }^{29}$

Az osztrák joggyakorlat a már meglévő jogszabályi keretek tágításával alakította ki a csoportos igényérvényesítés lehetőségét. ${ }^{30} \mathrm{~A}$ legnagyobb osztrák fogyasztóvédelmi szervezet a VKI (Verein für Konsumenteninformation) 2001-ben kifejlesztett egy speciális kollektív fellépési lehetőséget a tömeges igények kezelésére. Ennek segítségével lehetőség nyílt például a nagyszámú áldozattal járó balesetekből származó követelések érvényesítése, valamint a több fogyasztót érintő, törvénysértő magatartást tanúsító vállalkozások elleni fellépésre. A mechanizmust nem hivatalosan „osztrák stílusú class action”-nek nevezték el, és elsődleges célja, hogy kollektív egyezség jöjjön létre a felek között a kártérítés elérése érdekében. A megoldás jellemzője, hogy a fogyasztók nagyobb csoportja az igényeit átruházhatja egy fogyasztóvédelmi szervezetre, amely képviseleti keresetet indíthat a bíróságon. Ezzel a peres eljárás finanszírozása megoldható. ${ }^{31} \mathrm{Az}$ igényeket a szervezethez kell benyújtani, amely azokat az eljárás előtt - vagy ennek elmulasztása esetén az eljárás során - összegyüjti, majd a szervezet a saját nevében a „perre okot adók összekapcsolása" révén perelheti be a károkozókat. Vagyis a később felperesként eljáró fogyasztóvédelmi szervezet az összes olyan fogyasztó követelésének érvényesítésére kap megbízást, akik azonos vagy legalábbis nagyon hasonló követelésekkel lépnek fel ugyanazon vállalkozás ellen, és akik hajlandók igényeiket a szervezetre átruházni. Ezt követően ez a szervezet egyetlen keresetet indít az alperes ellen. Az aggregát követelések pénzbeli értéke általában meglehetősen magas. Mivel a szervezetben - kereskedelmi alapon - az egyes igénylők együtt viselik a peres eljárás költségeit, lehetővé válik a fogyasztóvédelmi szervezet számára a per finanszírozása, ${ }^{32}$ a pénzügyi kockázat eloszlik. ${ }^{33} \mathrm{Az}$ osztrák Legfelsőbb Bíróság az első ilyen esetet követően úgy határozott, hogy az ilyen igényérvényesítés elfogadható, ha az igények, valamint az érintett tárgybeli és jogi kérdések lényegüket tekintve hasonlóak. ${ }^{34}$

29 KLAUSER, Alexander: Class Actions-Austria, https://gettingthedealthrough.com/area/82/jurisdiction/25/classactions-austria/ (2017. 12. 28.).

30 CORAPI, Diego: Class actions and collective actions. In: Fairgreieve, Duncan-Lein, Eva (szerk.): Extraterrioriality and Collective Redress. Oxford University Press, Oxford, 2012, 9.

31 KODEK (2017): i. m., 120.

32 KARTSTEN: i. m., 36.

33 KODEK (2017): i. m., 120.

34 Oberster Gerichtshof 4 Ob 116/05w JBI 2006, 48, https://www.ris.bka.gv.at/JustizEntscheidung.wxe?Abfrag e=Justiz\&Dokumentnummer=JJT_20050712_OGH0002_0040OB00116_05W0000_000\&IncludeSelf=True (2017. 12. 30.). 


\subsection{A fellépésre jogosultak}

A fellépésre jogosultak körét a fogyasztói ügyekben a KSchG határozza meg. ${ }^{35}$ A törvény különbséget tesz a nemzeti és a határokon átnyúló jogsértések között. Csak az Európai Unió Bizottságának listáján szereplő minősített szervezetek ${ }^{36}$ jogosultak határokon átnyúló ügyekben eljárás kezdeményezésére. Az osztrák Szövetségi Gazdasági, Család- és Ifjúsági Minisztérium nyolc olyan minősített szervezetet jelentett be a Bizottságnak, amelyek jogosultak a tagállamokon átnyúló jogsértésekkel szembeni fellépésre. Külön kritériuma nincs a listára való felvételnek, minden olyan szervezet részesévé válhat, amely a nemzeti jog szerint is fellépésre jogosult. A tagállami szinten bekövetkező nemzeti jogsértések esetén a fellépésre jogosultak köre bővebb, a szociális érdekérvényesítő szervezetek, a szakszervezeteket, a kereskedelmi és iparkamarák, a nyugdíjasok szervezete, valamint a fogyasztóvédelmi szervezetek is rendelkeznek jogosultsággal. Ezek közül három szervezet végzi a legjelentősebb bíróság előtti tevékenységet: a VKI (Verein für Konsumenteninformation) a pénzügyi szolgáltatások, a biztosítások, a távközlés, valamint a megtévesztő és agresszív kereskedelmi gyakorlatok terén, a WZ (Schutzverband gegen Unlauteren Wettbewerb) szintén a tisztességtelen kereskedelmi gyakorlatok, végül a BAK (Bundesarbeitskammer) a távértékesítés, a távközlés, az utazásszervezés és a fogyasztók megtévesztése területén. 2017-ben alapítottak egy új kollektív jogorvoslatot támogató egyesületet (COBIN - COnsumers-Business-INvestors), melynek célja különösen „osztrák stílusú class action” szervezése, indítása és ehhez megfelelö pénzeszközök biztosítása. ${ }^{37}$

\subsection{A fellépések a gyakorlatban}

Ausztriában az igényérvényesítési eljárásokról szóló, nyilvánosan elérhető statisztikák nincsenek. A fellépésre jogosult szervezetek saját tevékenységükkel kapcsolatos adatokat gyüjtenek, de közös adatbázist nem hoztak létre. ${ }^{38} \mathrm{Az}$ „osztrák stílusú class action” rendkívül fontos a gyakorlatban, jól müködik, ${ }^{39}$ tömeges jogsérelmek esetén számos esetben sikeresen alkalmazták, például a bankokkal szemben vagy rossz befektetési tanácsadással kapcsolatos perekben. ${ }^{40} \mathrm{~A}$ gyakorlati tapasztalatok azt mutatják, hogy a rendelkezésre álló kollektív fogyasztóvédelmi eszközök igénybevételével való fenyegetés, vagy az ilyen per tényleges elindítása gyakran gyorsan és hatékonyan eredményezi a felek között a jogsértő helyzet megszüntetésére irányuló megállapodás létrejöttét. A közigazgatási hatósági eljáráshoz képest jóval nagyobb a peres eljárás költségkockázata a vállalkozás oldalán. Emellett a

35 KSchG 29. §.

36 Az Európai Unió Bizottsága által vezetett minősített szervezetek listája a következő linken érhető el: http:// eur-lex.europa.eu/legal-content/HU/TXT/HTML/?uri=OJ:C:2016:361:FULL\&from=EN (2018. 01. 21.).

37 KODEK (2017): i. m., 121.

38 KARTSTEN: i. m., 32.

39 KODEK (2015): i. m., 137.

40 KodeK (2017): i. m., 120. 
bírósági eljárás tekintélyesebb fenyegetés, mint a hatósági eljárás. A peren kívüli egyeztetésekkel általában nem lehet elérni a jogkövető magatartást, míg a bírósági eljárásban alkalmazható szankciók kilátásba helyezésének van visszatartó ereje a vállalkozások számára. Ilyen pereket csak civil szervezetek indítanak, viszont ezeknél a szervezeteknél a per finanszírozása alapvető probléma, így annak biztosítása nélkül a fogyasztók védelmével foglalkozó civil szervezetek nem lépnek fel. ${ }^{41}$ Ausztriában tiltott a felperes ügyvédi sikerdíjának megtérítése ${ }^{42}$ ezért vitatott, hogy a perek esetleges harmadik fél általi ilyen jellegü finanszírozása ellentétes-e vagy sem az osztrák jog ezen rendelkezésével. Alig van ezzel kapcsolatos esetjog, egy ügyben az osztrák Legfelsőbb Bíróság (Oberster Gerichtshof) úgy határozott, hogy az alperes nem hivatkozhat pergátló kifogásként érdemben a finanszírozás mikéntjére, a harmadik fél oldaláról történő finanszírozás a követelések jogosultjai és a pert finanszírozó közötti kérdés. ${ }^{43}$ Mindezeken túl megjegyzendő, hogy a polgári peres eljárás mellett a fogyasztók védelme érdekében széles körben alkalmazhatók a büntetőeljárásban rendelkezésre álló intézkedési eszközök is. ${ }^{44}$

Ausztriában annak ellenére, hogy előfordulnak külföldi vállalkozások által az osztrák fogyasztók sérelmére elkövetett jogsértések, ${ }^{45}$ és a fogyasztók jogait védő említett szervezetek egytől egyig szerepelnek az Európai Unió Bizottságának minősített szervezetek listáján, kizárólag a nemzeti bíróságok előtt indítanak eljárást belföldi jogsértések miatt. A határokon átnyúló jogsértések miatt nem indulnak eljárások, ${ }^{46}$ amelynek több oka is kimutatható. A visszatartó tényezők közül a nyelvi akadály, a külföldi ügyvédek alkalmazása, a tanúk vonakodása egy másik tagállamba való utazás kapcsán, a magas utazási költségek (ügyvédek, tanúk) és az eljárási törvények különbségei voltak a legjelentősebbek, de számos más, alapvetően eljárási jogi nehézség is felmerül. ${ }^{47} \mathrm{~A}$ kereset és az írásbeli bizonyítékok, egyéb okiratok fordítása és külföldi kézbesítése is jelentős akadálynak minősülnek. A bíróság döntésének való érvényszerzés is ugyancsak problémás egy másik tagállamban. Például Ausztriában a bíróság által meghatározott kötelezettség teljesítésének elmulasztása miatt kiszabott bírság nem része a bírósági döntésnek, hanem arról a bírósági

41 A Verein für Konsumenteninformation (VKI) 75\%-ban önfinanszírozott és 25\%-át a szociális partnerek és az állam finanszírozza. A Schutzverband gegen Unlauteren Wettbewerb 100\%-ban tagdíjakból önfinanszírozott. A Bundesarbeitskammer a munkavállalók és alkalmazottak kötelező képviselete, a pereket a 3,25 millió tag tagdíjából fedezik.

42 Ez azonban nem vonatkozik a teljesítményalapú díjazásra és arra az esetre, ha a sikerdíj mellett a sikertelen perlés esetére is hasonló összeg van kikötve. Lásd KODEK (2017): i. m., 365.

43 KLAuSer: i. m.

44 Kartsten: i. m., 43.

45 Például nyereményjátékok, promóciós utak, lottó, távértékesítés és utazási szerződések, félrevezető reklám, vagy a szolgáltatás leírása megtévesztő. KARTSTEN: i. m., 33.

46 A VKI 40-50 keresetéből csak egy érint külföldi vállalkozást.

47 Egy esetben a legnagyobb osztrák fogyasztóvédelmi szervezet, a VKI (Verein für Konsumenteninformation) a GMX németországi e-mail-szolgáltató fogyasztói szerződéseiben alkalmazott tisztességtelen általános szerződési feltételek miatt peren kívüli eljárást indított a céggel szemben. A GMX az eljárásban nyilatkozatban vállalta, hogy megszünteti a jogsértést, ellenkező esetben pedig bírságot fizet. Mivel a szerződés ellenére a jogsértést továbbra is folytatta a cég, a VKI megpróbálta érvényesíteni a szerződéses bírságot, de az eljárási szabályok (Gesetz vom 27. Mai 1896, über das exekutions- und Sicherungsverfahren - Exekutionsordnung - EO) eltérései miatt nem sikerült azt érvényesíteni. 
végrehajtásról szóló törvény rendelkezik. ${ }^{48}$ Németországban viszont a kötelezettség teljesítésének elmulasztása miatti bírság a kötelezésről szóló bírósági döntés rendelkező részében szerepel. A gyakorlatban ez azzal a következménnyel jár, hogy ha a végrehajtás Ausztriában nem lehetséges (például ha nincs a vállalkozásnak olyan vagyona, amit be lehetne hajtani Ausztriában), azt Németországban kell végrehajtani. Viszont a német bíróságok az eljárásjogi ellentétre tekintettel megtagadják a végrehajtást. ${ }^{49}$

\section{Olaszország}

\subsection{Kollektív igényérvényesítési lehetőségek}

Olaszországban általános kollektív igényérvényesítési mechanizmus nem létezik, ${ }^{50}$ vannak azonban ágazati kollektív fellépési lehetőségek a fogyasztóvédelem, a versenyjog, a közigazgatás, a munkajog és a környezetvédelem területén. ${ }^{51}$ A 2005ben hatályba lépett fogyasztókról szóló törvényerejü rendelet (Codice del consumo) ${ }^{52}$ 2009-es módosítása akként rendelkezik, ${ }^{53}$ hogy homogén és egyéni igényekkel rendelkező ${ }^{54}$ fogyasztóknak jogukban áll csoportkeresetet (azione di classe) benyújtani szerződésszegés, tisztességtelen vagy versenyjogsértő kereskedelmi gyakorlat, valamint termék- vagy szolgáltatásnyújtáshoz kapcsolódó felelősség miatt. A kereset bírósághoz történő benyújtását követően értesíteni kell mind az alperest, mind az ügyészt. Az ügyész ezután részt vehet az eljárásban, és állásfoglalást foglalhat a bíróság döntéshozatalát elősegítve - az ügy érdeme kapcsán. ${ }^{55}$ Ezáltal vegyes rendszert hozott létre az olasz jogalkotó, az egyedi igények megtérítésére irányuló kollektív igényérvényesítési eljárás egyben közérdekű elemet is tartalmaz.

$\mathrm{Az}$ azione di classe opt-in mechanizmuson alapul. Amennyiben a fogyasztó azt szeretné, hogy a bírósági döntés hatálya rá is kiterjedjen, beadványt kell benyújtatnia a bírósághoz, melyben felsorolja azokat a ténybeli és jogi elemeket, amelyekre igényét alapítja. Ez viszont nem jelenti azt, hogy az igényét bejelentő fogyasztó ténylegesen részt vesz a bírósági eljárásban. ${ }^{56}$ Viszont ha a fogyasztó úgy dönt, hogy nem csatlakozik az eljáráshoz, önállóan is élhet perindítással. Továbbá, ha az azione di classe vezető felperese egyezséget köt a perbe fogott vállalkozással, a

48 Exekutionsordnung (EO).

49 KARTSTEN: i. m., 47.

50 Devroe, Wouter: Remedies of Infringements of the Competition Provision. In: Hartkamp, Arthur-Sieburg, Carla-Devroe, Wouter: Cases, Material and Text on European Law and Private Law. Hart Publishing, Oxford, 2017, 156.

51 A munkajog és a környezetvédelem kapcsán rendelkezésre álló eljárások nem bírnak a gyakorlatban jelentőséggel, így ezek bemutatására nem kerül sor.

52 Codice del consumo Decreto legislativo, 06/09/2005 n² 206, G.U. 08/10/2005.

53 Art. 140.

54 Corapi: i. m., 8.

55 CAvani, Rafaele-Fossatı, Bruna Alessandra: Class and Group Actions 2018 - Italy. https://iclg.com/practiceareas/class-and-group-actions-laws-and-regulations/italy (2018. 01. 15.).

56 CorapI: i. m., 8. 
perhez csatlakozott fogyasztó dönthet úgy, hogy nem kívánja, hogy az egyezség hatálya kiterjedjen rá. Ebben az esetben ugyancsak önállóan indíthat pert. Az első tárgyalás során a bíróság megvizsgálja, hogy az igényét bejelentő fogyasztó tényleges érdekeltsége fennáll-e, dönt a kérelem elfogadhatóságáról, és megállapítja, hogy a tagok igénye homogén-e. (Az egyneműség az olasz jogban nem teljes azonosságot jelent.) Dönt arról is, hogy a fő felperes megfelelően fogja-e képviselni a csoport érdekeit, mely során figyelembe veszi, hogy rendelkezik-e elégséges gazdasági és szervezeti eszközökkel az eljárás előzetes szakaszában a közzétételi kötelezettség teljesítéséhez, valamint képes-e viselni az érdemi szakaszban az eljárási költségeket. Amennyiben a bíróság a keresetet elfogadhatónak nyilvánítja, meghatározza azokat a követelményeket, amelyeket minden fogyasztónak teljesítenie kell ahhoz, hogy a csoport tagjává válhasson. A döntést a felperes költségére közzéteszik, és megkezdődik az eljárás érdemi szakasza. Ha a bíróság megállapítja a vállalkozás felelősségét, akkor meghatározza a kompenzációs kártérítés összegét vagy pontos összeg helyett egységes kritériumokat állapít meg. ${ }^{57} \mathrm{Az}$ olasz jog büntető kártérítést nem tesz lehetővé. ${ }^{58}$

A közigazgatás területén a 198/2009 törvényerejü rendelet ${ }^{59}$ alapján - a közfeladatok helyes ellátásának elősegítése érdekében - ugyancsak lehetőség van kollektív fellépésre. A közigazgatási kollektív fellépés közérdekü igényérvényesítés, fö célja a közigazgatás feletti külső igazságügyi kontroll elősegítése, a közigazgatás minőségére, költséghatékonyságára és időszerüségre vonatkozó előírásoknak való megfelelés előmozdítása, melyre fogyasztóvédelmi hatósági ügyekben is sor kerülhet. A perindításra okot adhat a közigazgatási szolgáltatást igénybe vevő számos személyt érintő sérelem, a közigazgatási szolgáltatás minőségére, költséghatékonyságára vonatkozó szabályok megsértése, a közszolgáltatásokra vonatkozó szerződés feltételeinek megszegése, továbbá közigazgatási jogszabály megsértése. $A z$ eljárás opt-in jellegü, és a közigazgatási peres eljárás szabályai szerint folyik. $A z$ igényérvényesítő köteles a kereset megindítása előtt a közigazgatási szervnek felhívást küldeni, amely alapján a közigazgatási szervnek lehetősége van a követelt tevékenység önkéntes teljesítésére. A kereset alapossága esetén a közigazgatási szervnek az ítéletben foglaltaknak megfelelően kell eljárnia. Kártérítési igények rendezésére nincs lehetőség, az olasz jog kifejezetten tiltja a közigazgatással szembeni kártérítési keresetek indítását. ${ }^{60}$

57 RAJNERI, Eleonora-Poncibò, Cristina: Focus on Collective Redrress - Italy. https://www.collectiveredress.org/ collective-redress/reports/italy/overview (2018. 01. 14.).

58 Cavani-Fossati: i. m.

59 Decreto Legoslativo 20 dicembre 2009, n. 198 Attuazione dell'art. 4 della legge 4 marzo 2009, n. 15, in materia di ricorso per l'efficienza delle amministrazioni e dei concessionari di servizi pubblici.

60 RAJNERI-PONCIBÒ: i. m. 


\subsection{A fellépésre jogosultak}

Az azione di classe alapján fellépésre az érintett fogyasztók egyénileg jogosultak, vagy az igényük érvényesítésére mandátumot adhatnak valamilyen egyesületnek. Az első jogszabályszöveg-változat - amely végül nem lépett hatályba - egyébként csak fogyasztói szervezeteknek engedte volna meg a perindítást. ${ }^{61} \mathrm{~A}$ közigazgatási kollektív fellépésre azok jogosultak, akik olyan konkrét érdekkel rendelkeznek, amely az adott helyzetnek megfelelö jogi védelem alá tartozik. ${ }^{62}$

\subsection{A fellépések a gyakorlatban}

Az első kereset benyújtására 2010-ben került sor a Milánói Bíróság előtt. ${ }^{63}$ A 2016 januárjáig rendelkezésre álló adatok szerint ötvennyolc azione di classe megindítására került sor. ${ }^{64} \mathrm{Ez}$ nem tekinthető az egész országra vetítve jelentős számnak. Az azione di classe - a várakozásokkal ellentétben - nem gyakorolt jelentős hatást a fogyasztói igényérvényesítés helyzetére Olaszországban, a benyújtott kezdeményezések közül a bíróságok csak néhányat fogadtak el. Ennek okai, hogy a per finanszírozása teljes egészében a vezető igényérvényesítőre (felperesre) hárul, valamint a pernyertes alperes vállalkozás a vezető igényérvényesítővel szemben követelheti az ügyvédi dijjak és további károk megtérítését. Határokon átnyúló jogsértések kapcsán azione di classe indítására nem került sor. Közigazgatási kollektív fellépés eddig négy esetben történt. ${ }^{65}$

\section{Franciaország}

\subsection{Kollektív igényérvényesítési lehetőségek}

Franciaországban a kollektív mechanizmusok szektorálisak, ${ }^{66}$ a polgári perek mellett a közigazgatási eszközök és a büntetőjogi felelösségre vonás párhuzamosan, egymást kiegészítve jelennek meg. Az ágazati mechanizmusok a fogyasztók jogai, a versenyjog, az egészségügyi jog (kártérítési), a hátrányos megkülönböztetés, a környezetvédelmi jog (eltiltási és kártérítési), valamint az adatvédelem (eltiltási) terén léteznek. ${ }^{67}$

61 CoRAPI: i. m., 8.

62 CaVAnI-Fossati: i. m.

63 Fairgreieve, Duncan-Howells, Geraint: Collective Redress Procedures: Europien Debates. In: Fairgreieve, Duncan-Lein, Eva (szerk.): Extraterrioriality and Collective Redress. Oxford University Press, Oxford, $2012,26$.

64 Forrás: http://www.osservatorioantitrust.eu/it/azioni-di-classe-incardinate-nei-tribunali-italiani/ (2017. 01. 14.).

65 RAJNERI-PONCIBÒ: i. m.

66 DeVroe: i. m., 155.

67 FaIRgrieVe, Duncan-Bonze, Constance: Empirical Reports, France. In: State of Collective Redress in the EU in the Context of the Implementation of the Commission Recommendation (2013/396/EU). British Institute of International and Comparative Law, 2017, 170. 
A közösségi fogyasztóvédelmi jogot átültető rendelet ${ }^{68}$ alapján a fogyasztók védelmére felhatalmazott szervezeteknek többféle lehetősége is van a bíróság előtti igényérvényesítésre. Jogosultak a fogyasztók jogait sértő gyakorlatok megszüntetése iránti kereset (action en cessation de pratiques illicites), ${ }^{69}$ polgári peres kereset (action civile), ${ }^{70}$ közös képviseleti kereset benyújtására (action en représentation conjointe), ${ }^{71}$ tisztességtelen szerződési feltételek alkalmazása miatt is bírósághoz fordulhatnak (action en suppression de clauses abusives), ${ }^{72}$ valamint jogosultak jogellenes magatartás megszüntetése érdekében is pert kezdeményezni (action en conduite illicite). ${ }^{73}$ Tehát Franciaországban a fogyasztóvédelmi szervezetek bővelkednek a fogyasztók igényérvényesítése iránti fellépési lehetőségekben, és a 2009/22/EK irányelvnek nem volt jelentős hatása a francia jogra. ${ }^{74} \mathrm{~A}$ rendelkezésre álló peres lehetőségek mellett gyakran alkalmazzák a mediáció eszközét is, amelynek gyakorlati hatásaként a peres eljárások száma nem emelkedik.

Az elöbbiekben felsorolt fellépési lehetőségekre a fogyasztók kollektív érdekének megsértése esetén van lehetőség ${ }^{75}$ ezek közérdekü fellépési mechanizmusok. Az egyedi fogyasztói igények összevont érvényesítése (action de collectif) 2014 óta lehetséges Franciaországban. Az első lépés a fogyasztóvédelmi törvény 2014. március 14-én történt módosítása (ún. Hamon-törvény), ${ }^{76}$ továbbá a végrehajtási rendelet megalkotása ${ }^{77}$ valamint a fennmaradó kérdéseket tisztázó körlevél ${ }^{78}$ volt. A francia jogalkotó ezáltal egy külön fejezetet adott hozzá a francia fogyasztóvédelmi törvényhez. Ezenfelül módosították az igazságszolgáltatás szervezetét szabályozó törvényt (Code de l'Organisation Judiciaire) és a polgári perrendtartást (Code de procédure civile) is. A módosítás azonban elég szükre szabta a lehetőségeket, a csoportos kereset hatóköre a fogyasztóvédelemben csak a tizenöt nemzeti fogyasztói szövetségre és az áruk értékesítéséből, a szolgáltatások nyújtásából és a versenyellenes gyakorlatokból származó károkra vonatkoztak. ${ }^{79} \mathrm{~A}$ jogalkotó 2016ban a fellépési lehetőségeket bővítette, de nem a fogyasztóvédelemben, hanem az egészségügy, az adatvédelem, a környezetvédelem, a munkavállalók védelme, a befektetők védelme és az esélyegyenlőség területein tette lehetővé széles körben a kollektív perindítást. ${ }^{80}$

68 Ordonnance no 2001-741 du 23 août 2001 portant transposition de directives communautaires et adaptation au droit communautaire en matière de droit de la consommation. JORF n¹96 du 25 août 2001 page 13645 texte $n^{\circ} 6$.

69 Ordonnance 2001-741 Art. L. 421-6 C.Cons.

70 Ordonnance 2001-741 Art. L. 421-1 C.Cons.

Ordonnance 2001-741 Art. L. 422-1 C.Cons.

Ordonnance 2001-741 Art. L. 421-6 C.Cons.

Ordonnance 2001-741 Art. L. 421-2 C.Cons.

KaRTSTEN: i. m., 66.

75 Fairgreieve Howells: i. m., 23.

76 Loi n 2014-344 du 17 mars 2014 sur la consommation, L.623-1-623-32.

77 Décret No. 2014-1081, 2014. 09. 24.

78 JUSC 1421594.

79 Lustin-Le CORE, Céline: Class Actions - France. https://gettingthedealthrough.com/area/82/jurisdiction/28/ class-actions-france/ (2017. 12. 28.).

80 SPORTES, Carole-Ravit, Valérie: Class and Group Actions Laws and Regulations 2018 - France. https://iclg. $\mathrm{com} /$ practice-areas/class-and-group-actions-laws-and-regulations/france (2018. 01. 08.). 
Egy 2017. május 6-án hatályba lépett rendelet ${ }^{81}$ pedig létrehozta a közös eljárási alapot valamennyi ilyen típusú kollektív igényérvényesítési formára vonatkozóan, mivel a francia jog szerint a különböző keresetek polgári vagy közigazgatási bírósághoz is benyújthatók, attól függően, hogy az alperes közintézmény-e vagy sem.

\subsection{A fellépésre jogosultak}

A francia jogrendben az egyes ágazatokban müködő szervezetek felelősek a kollektív érdekek védelméért. ${ }^{82}$ Ez nemcsak a fogyasztóvédelem terén van így, hanem az egészségügy, az egyenlö bánásmód, a környezetvédelem, a befektetővédelem és a munkavállalók védelme eseteiben is. ${ }^{83}$ Franciaországban tizenöt olyan szervezet müködik, amely a fogyasztók védelmében végzi tevékenységét. Ezeknek a nagyobb része nem indít bírósági eljárásokat, és csak kettő olyan szervezet van (az UFC-Que Choisir és a Consommation Logement et Cadre de Vie - CLCV), amelyek képesek a határokon átnyúló jogsértések miatt is fellépni. A fogyasztóvédelmi szervezetek fő tevékenysége a fogyasztók részére biztosított jogi tanácsadás, és az utóbbi két szervezet indít eljárásokat a fogyasztók kollektív érdekeinek védelme érdekében. Az állami támogatáshoz való jogosultságot a jogszabályi előírások szerint $^{84}$ az a fogyasztóvédelmi szervezet szerezheti meg, amely nemzeti szintű reprezentativitással rendelkezik, vagyis legalább 10000 fös tagsággal bír. Ezeken felül Franciaországban a Versenypolitikai, Fogyasztóvédelmi és Csalásellenörzési Föigazgatóság (DGCCRF) (állami szerv), ugyancsak jogkörrel rendelkezik arra, hogy eljárást indítson a fogyasztók jogait sértő magatartások megszüntetése érdekében, illetve tisztességtelen szerződési feltételek alkalmazása miatt. ${ }^{85}$

\subsection{A fellépések a gyakorlatban}

Franciaországban az eljárási szabályok meglehetősen bonyolultak, ${ }^{86}$ ennek ellenére a kollektív fogyasztói érdekeket védő eljárásokat sikerrel alkalmazták a banki szolgáltatások, az ingatlanközvetítés, az online szállásfoglalás, a tömegközlekedés, a telekommunikáció, az egészségre vonatkozó valótlan állítások, a nem élelmiszer jellegủ termékek, a lottó, valamint a háztartási szolgáltatások terén. A csoportos kereseteket pedig föleg balesettel járó utazás miatt indítottak. ${ }^{87}$

A fellépésre jogosult szervezeteknek a jogszabályok ugyan nem biztosítanak lehetőséget arra, hogy az egyedi fogyasztói igények kielégítése érdekében pert indíthassanak, viszont nemcsak jogszabálysértő tevékenység megszüntetését kérhetik

81 Décret No. 2017-888.

82 FairgreieVe-Howells: i. m., 23.

83 SPORTES-RAVIT: i. m.

84 Ordonnance 2001-741 Art. R 411 C.Cons.

Kartsten: i. m., 68.

36 Molfessis, Nicolas: L'exorbitance de l'action de groupe à la française. Recueil Dalloz, 2014, 947.

87 Fairgrieve-Bonze: i. m., 171. 
a bíróságtól, hanem a fogyasztói igények összegyüjtése révén, a kollektív érdekek érvényesítése érdekében történő fellépéssel (intérêt collectif des consommateurs) kártérítési kötelezettség megállapítását is. A 2014 előtti francia jogrend nem tette lehetővé a fogyasztói jogokat védő szervezetek számára, hogy az egyéni károk megtérítése érdekében fellépjenek. Még közös képviseleti kereset (action en représentation conjointe) indítása esetén sem, amely eljárási rezsim egyébként lehetőséget ad a feljogosított szervezetek számára, hogy azon jogsértéssel érintett fogyasztók nevében jóvátételt követeljenek, akik átengedik igényüket a szervezetnek. Már önmagában ez is jelentős segítséget jelentett a jogsértés áldozatává vált fogyasztók számára. ${ }^{88} \mathrm{~A} 2014$-ben bevezetett class action jellegű eljárásban viszont már nyertes per esetén a kártérítési összeget a perben részt vett szervezet osztja el az osztály tagjainak száma szerint, vagy pedig a szervezetet a perbíró is felhatalmazhatja arra, hogy ügyvédet vagy végrehajtót kérjen fel segítségként a fogyasztói csoport tagjai közötti kompenzáció elosztására. A szabályozás hiányossága az, hogy a törvény nem tartalmaz semmilyen rendelkezést az esetlegesen fennmaradó fel nem osztott összegekről. ${ }^{89} \mathrm{~A}$ bírósági költségeket általában a vesztes fél viseli. ${ }^{90}$

A határon átnyúló jogsértések miatti fellépés Franciaországban nem jellemző. A DGCCRF már indított bírósági eljárást külföldi jogsértés miatt, de Franciaországban is csak néhány ilyen ügy volt ${ }^{91} A$ tapasztalatok azt mutatják, hogy ha a belföldi bíróságok marasztaló döntést is hoztak olyan külföldi vállalatokkal szemben, amelyek francia fogyasztókkal szemben követtek el jogsértést, az ítéletek végrehajtása, vagyis a bírói döntésben foglaltak külföldön való érvényesítése jelentős eljárásjogi és anyagi nehézségekbe ütközött. ${ }^{92}$

\section{Portugália}

\subsection{Kollektív igényérvényesítési lehetőségek}

Portugáliában egy általános, viszont igen széles körben alkalmazható közérdekủ igényérvényesítési típus van, melyet kiegészítenek a fogyasztóvédelmi, pénz-

88 KaRTSTEN: i. m., 70.

89 Lustin-Le CORE: i. $\mathrm{m}$.

90 FAIRGRIEVE-BonZE: i. m., 170.

912008 és 2012 között két ügy indult tagállamokon átnyúló jogsértés miatt. A DGCCRF több külföldi fogyasztóvédelmi hatóság kérésére egy francia weboldal üzemeltetője ellen uniós fogyasztóvédelmi szabályok megsértése miatt a Tribunal de grande instance de Paris indított eljárást. Egy másik esetben az UFC megpróbált határokon átnyúló eljárást indítani egy francia-svájci ügyben. A Tribunal de Commerce d'Avignon azonban azt állapította meg, hogy nemzetközi joghatósággal nem rendelkezik az ügyben. Bár nem tekinthető az irányelv által vett értelemben határokon átnyúló jogsértés miatti fellépésnek, de a fellépések egyedülálló összehangoltsága miatt érdemes megemlíteni a Franciaországot, Portugáliát és Belgiumot érintő esetet, amikor légitársaságok viteldijainak átláthatatlansága miatt lépett fel összehangoltan az UFC-Que Choisir a DECO (Portugália) és a Test-Achats (Belgium) a társaságokkal szemben, az alkalmazott általános szerződési feltételek tisztességtelensége miatt. Marasztaló döntést végül a belga bíróság hozott.

92 KARTSTEN: i. m., 68. 
ügyi és környezetvédelmi jogi rendelkezések. ${ }^{93} \mathrm{Ez}$ egyfajta „népi kereset” (acção popular), melynek alapját a Portugál Köztársaság Alkotmánya rögzíti (Constituição da República Portuguesa), ${ }^{94}$ és ezt kiegészíti a kollektív keresetről szóló 1995. augusztus 31-i 83/95 törvény, amely a részletes szabályokat tartalmazza. ${ }^{95}$ Ezek a rendelkezések biztosítják, hogy az állampolgárok befolyással lehessenek a bírósági és közigazgatási döntésekre. Az acção popular több típusáról is rendelkezik a portugál jog: megelőzésre, közigazgatási döntések megtámadására, valamint kártérítésre irányuló acção popular különböztethető meg. Az acção popular a portugál alkotmány rendelkezése alapján ${ }^{96}$ különböző közérdekủ esetkörökben széles körben alkalmazható, elsősorban: közegészségügy, környezetvédelem, emberi életminőség védelme, fogyasztóvédelem, kulturális örökség és közkincsek védelmében. ${ }^{77}$ Ebböl kifolyólag az ágazati jogszabályok nem tartalmaznak külön eljárásrendet, hanem a 83/95 törvényre utalnak vissza. ${ }^{98} \mathrm{Az}$ eljárás eredménye két típusú lehet: kártérítés vagy intézkedések megtételének előirása. A jogerős ítélet két újságban a jogsértő költségére közzétételre kerül. ${ }^{99}$

A kérelem elutasítása esetén, azaz ha a bíróság úgy ítéli meg, hogy az eljárás nem folytatható le, a bíróság szükség esetén konzultál az ügyésszel, továbbá abban az esetben is, ha az ügyész, illetve a kérelmező erre vonatkozóan előzetes vizsgálatot kér. ${ }^{100}$

A vállalkozás elmarasztalása esetén a bírósági ítélet jogeröre emelkedése után három éven belül a kártérítés iránti igények elévülnek. A 83/95 törvény 22. cikke szerint az elévülési idő lejártáig a jogosult által nem követelt kártérítési összeg az Igazságügyi Minisztériumra száll, amelyböl megfizeti a fennmaradó eljárási költségeket, és a fel nem használt összeget pedig az igazságszolgáltatáshoz való hozzáférés elősegítése érdekében kollektív jogérvényesítést folytató szerveknek nyújtja. ${ }^{101}$

A fogyasztóvédelemről szóló $24 / 96$ törvény ${ }^{102}$ alapján a fogyasztók jogainak megsértése esetén - a jogsértés megszüntetése érdekében - is lehetővé teszi a közérdekű igényérvényesítést (acçãos inibitórias). A törvény nem szabályozza külön magát a kollektív jogorvoslati mechanizmust, hanem kimondja, hogy az általános

93 Vale e Reis, Rafael: Empirical Reports, Portugal. In: State of Collective Redress in the EU in the Context of the Implementation of the Commission Recommendation (2013/396/EU). British Institute of International and Comparative Law, 2017, 236.

94 Constituição da República Portuguesa. Különösen az 52., 3. és 60. cikk 3. bekezdéseiben.

95 Lei n. ${ }^{\circ} 83 / 95$, de 31 de Agosto, Direito de participação procedimental e de acção popular.

96 Constituição da República Portuguesa 52. cikk.

97 Corapi: i. m., 9.

98 A portugál törvények szerint a fogyasztóvédelmi ügyekben és a kulturális örökség védelme esetén az ügyésznek is van fellépési joga. Lásd Lei n. ${ }^{\circ} 24 / 96$, de 31 de Julho Lei de defensa do consumidor 13. cikk; Lei n. ${ }^{\circ} 107 / 2001$, de 08 de Setembro Lei de bases do património cultural 9. cikk.

99 Vale e ReIs, Rafael-Mesquita, Miguel: Focus on Collective Redress - Poerugal. British Institute of International and Comparative Law, https://www.collectiveredress.org/collective-redress/reports/portugal/ (2017. 12. 29.).

100 Lei n. ${ }^{\circ} 83 / 95$, de 31 de Agosto, Direito de participação procedimental e de acção popular 13. cikk.

101 JÉzUS, Sanda-DıAS, Sandra Ferreira: Class Actions - Austria. https://gettingthedealthrough.com/area/82/ jurisdiction/20/class-actions-portugal/ (2017. 12. 30.).

102 Lei $n .{ }^{\circ} 24 / 96$, de 31 de Julho Lei de defensa do consumidor. 
processzus alkalmazandó. A gyakorlatban az acção inibitórias és az acção popular közötti különbség homályos és nincs gyakorlati jelentősége.

A fogyasztóvédelmi törvény mellett tisztességtelen általános szerződési feltételekről szóló 446/85 törvényerejủ rendelet ${ }^{103}$ rendelkezik arról, hogy általános szerződéses feltételek használata vagy alkalmazásra ajánlása miatt is lehetőség van perindításra. Továbbá az értékpapírkódexről szóló törvényerejü rendelet ${ }^{104}$ is biztosít kereshetőséget a fogyasztók, jelesül a nem üzleti befektetők védelme érdekében.

A közigazgatás területén az acção popularhoz hasonló kiegészítő jogintézményröl rendelkezik a 2004-ben hatályba lépett igazgatási bírósági reform, és lehetővé teszi az azonos típusú jogsértésekkel szembeni fellépést. ${ }^{105} \mathrm{~A}$ közigazgatási bírósági eljárásról szóló törvénykönyv ${ }^{106} 48$. cikke vezette be a „tömeges eljárás” (processos em massa) intézményét. Ebben a mechanizmusban, ha több mint húsz olyan ügyet indítanak bíróság előtt, amelyek jogilag vagy ténylegesen ugyanazon a viszonyból erednek, akkor csak egy vagy néhány kérelemröl dönt a bíróság mérlegelésétől függően, és a többi eljárást felfüggesztik. Az így meghozott döntés a késöbbiekben - a törvényi követelmények teljesülése esetén - alkalmazható a felfüggesztett ügyekre is.

\subsection{A fellépésre jogosultak}

Az acção popular mind polgári, mind közigazgatási bíróság előtt megindítható, attól függően, hogy a jogvita tárgyát közigazgatási jogi vagy polgári jogi rendelkezés képezi. A kezdeményezésre jogosultak köre rendkívül szélesen került meghatározásra, ezt Portugáliában a polgári és politikai jogok gyakorlása „élvezetének” tekintik. A perindításra bármely állampolgár vagy akár külföldi személy is jogosult. Ezenkívül olyan egyesületek és alapítványok is, amelyek a fent említett közérdekeket védik. Anyagi jogi értelemben vett közvetlen érdekeltség igazolása nem követelmény az igényérvényesítés gyakorlásához. ${ }^{107}$

Az eljárásban való érintettség opt-out alapon müködik, vagyis fő szabály szerint az igény érvényesítője minden érintett érdekében lép fel. ${ }^{108}$ Az eljáró bíróság megállapítja a jogsértéssel érintettek körét, akik meghatározott határidőn belül nyilatkozhatnak arról, hogy kivonják-e magukat az eljárás hatálya alól. Azon érintettek tekintetében, akik nem nyilatkoznak, a bíróság úgy tekinti, hogy elfogadták az érdekükben történő perindítást, és ebben az esetben az ítélet hatálya kiterjed rájuk. ${ }^{109}$ Az ügyésznek különösen fontos szerepe van az eljárásban. Az eljárásba beléphet a felsorolt közérdekek védelme érdekében, ha a felek közötti egyezségi megállapodás

103 DL n. ${ }^{\circ} 446 / 85$, de 25 de OutubroClausulas contratuais gerais 26 . cikk.

104 DL n. $^{\circ} 486 / 99$, de 13 de Novembro Código dos valores mobiliários.

105 Vale e Reis, Rafael: i. m., 236.

106 Código de Processo nos Tribunais Administrativos Lei $n^{\circ}$ 15/2002, de 22 de fevereiro.

107 Ilyen egyesületek például az Associação Portuguesa para a Defesa do Consumidor DECO (Portugál Fogyasztóvédelmi Egyesület) vagy a Quercus - Associação Nacional de Conservação da Natureza (Országos Természetvédelmi Egyesület). Lásd VALE E ReIS-Mesquita: i. m.

108 DeVRoE: i. m., 156.

109 Vale e Reis-Mesquita: i. m. 
nem tisztességes, vagy az eljárás kezdeményezést visszavonják. Az igényérvényesítő helyére léphet az eljárásban, ha annak magatartása sérti az alkotmány szerint védendő érdekeket, veszélyezteti a csoport érdekeit. ${ }^{110}$ Ilyen esetben az ügyész fellépése nem automatikus, hanem mérlegelésen alapul, figyelembe véve a közérdek megállapításhoz szükséges körülményeket. ${ }^{111}$

Az acção popular kérelmezőjének joga van büntetőeljárás kezdeményezésére az ügyésznél, és ebben az esetben résztvevője lesz a büntetőeljárásnak is. ${ }^{112}$

Az acção inibitórias szerinti fogyasztóvédelmi pert az érintettek, valamint a fogyasztóvédelmi szervezetek ${ }^{113}$ mellett indíthat az ügyész és a Fogyasztóvédelmi Főigazgatóság (Direção-Geral do Consumidor) is, ha a kollektív vagy diffúz egyéni érdekek sérülnek. ${ }^{114}$ A fogyasztók jogait érintő jogsértés alapja viszont korlátozott, hibás teljesítés miatti vagyoni és nem vagyoni kártérítés, vagy termékfelelősségen alapuló kártérítés lehet. ${ }^{115} \mathrm{Az}$ ügy a polgári bíróság elé tartozik, és az eljárás megegyezik az acção popular esetében lefolytatottal.

A tisztességtelen általános szerződési feltételekröl szóló 446/85 törvényerejü rendelet alapján keresetindításra jogosultak a reprezentativitással rendelkező fogyasztóvédelmi egyesületek, minősített szervezetek, valamint ügyészség hivatalból vagy az ombudsman jelzésére. Az értékpapírkódexről szóló törvényerejű rendelet szerint perbeli legitimációval azok a befektetővédelmi egyesületek és alapítványok rendelkeznek, amelyek fő célja a nem üzleti személy befektetők védelme, természetes személy tagjuk van, és több mint egy éve müködnek. ${ }^{116}$

\subsection{A fellépések a gyakorlatban}

Portugáliában az acção popular alkalmazására eddig kevés esetben ${ }^{117}$ került sor mind általánosságban, mind a fogyasztók jogainak megsértése miatt. ${ }^{118}$ Ennek oka - a Legfelsőbb Bíróság acção popular elemzéséről szóló esettanulmánya szerint - az, hogy a civil társadalom fejlődése még korai stádiumban van Portugáliában, valamint a 83/95 törvény gyakorlati alkalmazása körül sok kérdés van a joggyakorlatban. ${ }^{119}$ További probléma, hogy sem az erga omnes hatályú ítélet végrehajtására, sem az egyéb eljárási szabályok tekintetében nincsenek speciális rendelkezések,

110 VAle e ReIS: i. m., 236.

111 Lei n. ${ }^{\circ} 83 / 95$, de 31 de Agosto, Direito de participação procedimental e de acção popular 16. cikk 1.

112 Lei n. ${ }^{\circ} 83 / 95$, de 31 de Agosto, Direito de participação procedimental e de acção popular 25. cikk.

113 Portugáliában működő fogyasztóvédelmi szervezetek például az Associação Portuguesa para a Defesa do Consumidor (DECO), Associação de Consumidores (ACOP), União Geral de Consumidores.

114 Lei $n .^{\circ} 24 / 96$, de 31 de Julho Lei de defensa do consumidor 13. cikk.

115 Lei $n .{ }^{\circ} 24 / 96$, de 31 de Julho Lei de defensa do consumidor 12. cikk.

116 DL n. ${ }^{\circ} 486 / 99$, de 13 de Novembro Código dos valores mobiliários 31-32. cikkek.

117 Például: 1998 - Dulce Pontes Bizet's Carmen ügy elmaradt előadás jegyek árának visszatérítése miatt; 2002 - „Open School” ügy angol magániskolák visszatérítés nélküli bezárása miatt; 2006 - „Elromlott vízmérők" ügye meghibásodott vízmérők javítási költségeinek visszatérítése miatt; 2013 - Digital Terrestrial Television (DTTV) ügy a digitális televíziózásra történő átállás során történt mulasztások miatt.

118 JÉZUS-DIAS: i. $m$.

119 Vale e Reis-Mesquita: i. m. 
annak ellenére, hogy akár több száz fél is részt vehet az eljárásban. ${ }^{120}$ A 98/27/EK irányelv átültetéséről rendelkező $25 / 2004$ törvény ${ }^{121}$ hatálybalépése sem növelte a perindítások számát. A törvény hatálya az irányelv I. mellékletében felsorolt fogyasztói irányelvekre korlátozódik, és csak a minősített szervezetek számára teszi lehetővé az eljárás kezdeményezését. Ezzel szemben fogyasztói szerződésekben alkalmazott általános szerződési feltételek tisztességtelensége miatt számos bírósági eljárás indult már Portugáliában, és igen kiterjedt esetjog áll rendelkezésre ebben a körben. Föleg pénzügyi szolgáltatások kapcsán (bankok és biztosítók) alkalmazott tisztességtelen szerződési feltételek miatt történtek a perindítások. Rendszerint a költségek megtakarítása érdekében a fogyasztói szervezetek az ügyeket az ügyészséghez irányítják, amely mentes a „vesztes fizet” elv alkalmazásakor (gyakran jelentős) bírósági díjak és költségek alól. Az acção popular, illetve az acção inibitórias alapján született ítéleteket követően az egyes fogyasztók kártérítési igénnyel élhetnek a bíróságon, amely jelentősen megkönnyíti az egyéni igényérvényesítést. ${ }^{122}$

Portugáliában eddig egyetlen minősített fogyasztóvédelmi szervezet sem indított eljárást külföldi bíróság előtt határon átnyúló jogsértés miatt. Ennek oka alapvetően egyrészt a peres eljárással járó költségek finanszírozása, másrészt pedig az eljárás gyakorlati lebonyolításához szükséges szakmai feltételek hiánya a fogyasztóvédelmi szervezetek oldalán. Portugáliában a határokon átnyúló igényérvényesítési eljárások lehetősége nem ismert széles körben. Ebből kifolyólag a jogi szakemberek, ügyvédek nem keresik aktívan az ilyen perek megindításának lehetőségét, illetve nem is ismerik fel, hogy az adott ügy alkalmas lehetne ilyen eljárás megindítására. Az eljárások kezdeményezésének másik fö akadálya az, hogy magas költségekkel járnak, beleértve a bírósági díjakat és az ügyvédi költségeket is. Viszont külföldi vállalkozással szemben belföldi bíróság előtti eljárás kezdeményezésére már sor került az Associação Portuguesa para a Defesa do Consumidor (DECO) részéröl. A DECO 2009 májusában indított eljárást a francia UFC-Que Choisir és a belgiumi Test-Achats fogyasztóvédelmi szervezetek együttmüködésével légitársaságok által alkalmazott általános szállítási feltételek tisztességtelensége és a weboldaluk átláthatósága miatt. A DECO az eljárást alapvetően - a több mint 200000 fős tagsága révén - a tagbevételeiből finanszírozta. ${ }^{123}$

\section{Litvánia}

\subsection{Kollektív igényérvényesítési lehetőségek}

A kollektív igényérvényesítést lehetővé tévő mechanizmusokat meglehetősen régen bevezették a litván jogrendszerbe. Például a versenyjog területén 1999-ben, a csoportos igényérvényesítést pedig 2003-ban. A litván jog két általános kollektív

120 VALE e ReIs: i. m., 236-237.

121 Lei $n .^{\circ}$ 25/2004, de 8 de Julho Transpõe para a ordem jurídica nacional a Directiva n. ${ }^{\circ}$ 98/27/CE, do Parlamento Europeu e do Conselho, de 19 de Maio, relativa às acções inibitórias em matéria de protecção dos interesses dos consumidores.

122 VALe e ReIS-Mesquita: i. m.

123 KARTSTEN: i. m., 112-114. 
és négy ágazati kollektív mechanizmust ismer (két fogyasztóvédelmi, egy versenyjogi és egy környezetvédelmi). A két általános rendszerröl a polgári perrendtartás (Civilinio Proceso Kodekso) ${ }^{124}$ rendelkezik. Mindkettő közérdekü igényérvényesítés. Ezek a közérdek védelmére irányuló általános fellépések, valamint a közérdek védelmére irányuló csoportos fellépések. A perrendtartás vonatkozó rendelkezése ${ }^{125}$ szerint keresetet csak a törvényben meghatározott esetekben, és csak a közérdek védelmében lehet előterjeszteni. A törvény nem határozza meg a közérdek fogalmát, ezért a bíróságoknak minden esetben külön kell vizsgálniuk az eset körülményeit, figyelembe véve az ügy egyedi jellemzői kapcsán a közérdek sérelmének fennállását. Definíció hiányában a bírói joggyakorlat az érintett közérdeket szélesen értelmezi. ${ }^{126}$ A perben büntető kártérítés nem kérhetö. ${ }^{127}$

Az ágazati jogszabályokban két fogyasztói kollektív igényérvényesítési mechanizmus létezik. Ugyanúgy, mint az általánosak, ezek a típusok is közérdeküek. A fogyasztók kollektív érdekeinek védelmében indíthatók meg, abban az esetben, ha a fogyasztók törvény által védett kollektív érdekei sérülnek. A fogyasztókat érintő jogsértések esetén - az általános szabályok alapján - jogviszony elismerése vagy megváltoztatása iránt, jogsértő magatartás megtiltása (megszüntetése) iránt, valamint az eladó vagy a szolgáltató olyan mulasztása miatt nyújtható be, amely a fogyasztók jog által védett közérdekét sérti. Ezek mellett a vállalkozás olyan tevékenysége miatt is, amely nem felel meg a tisztességes piaci magatartásnak, valamint olyan tevékenység miatt, amely sérti a litván polgári törvénykönyv rendelkezéseit vagy bármely más jogszabályt. A másik ágazati fellépési lehetőség, hogy az Állami Fogyasztóvédelmi Hatóság (Valstybinè Vartotojų Teisių Apsaugos Tarnyba) törvényi felhatalmazása arra, hogy fogyasztói szerződések részévé váló tisztességtelen szerződési feltételek miatt indíthasson peres eljárást. ${ }^{128} \mathrm{Az}$ eljárásban magánszemélyek nem vehetnek részt, de az ítélet res iudicatát eredményez minden olyan ügyben, amely azonos vagy hasonló jogi helyzeten alapul, mint a közérdekü perben elbírált ügy, így az egyének ugyanezen tények alapján pert már nem kezdeményezhetnek. Az ítélet további jogkövetkezménye, hogy a perben kifogásolt szerződési feltétel tisztességtelenségének megállapítása esetén minden érintett szerződés kapcsán érvénytelenséget eredményez azzal a feltétellel, hogy a fogyasztó az ítélet alapján, arra hivatkozva egyedi szerződése kapcsán kéri annak módosítását, mely érdekében az Állami Fogyasztóvédelmi Hatóság is eljárhat.

A versenyjogi kollektív igényérvényesítés tisztességtelen versenymagatartás miatt alkalmazható. A környezetvédelmi kollektív fellépésre pedig a környezetvédelem és a természeti erőforrások hasznosításának megsértése esetén lehetséges,

124 Lietuvos Respublikos Civilinio Proceso Kodekso patvirtinimo, įsigaliojimo ir ịgyvendinimo j̨statymas $2002 \mathrm{~m}$. vasario $28 \mathrm{~d}$. Nr. IX-743, 9. cikk.

125 Civilinio Proceso Kodekso 49. cikk.

126 Mizaras, Vytautas: Focus on Collective Redrress - Lithuania. https://www.collectiveredress.org/collectiveredress/reports/lithuania/overview (2018. 01. 14.).

127 Bubliene, Danguole-Mizaras, Vytautas: Empirical Reports, Lithuania. In: State of Collective Redress in the $E U$ in the Context of the Implementation of the Commission Recommendation (2013/396/EU). British Institute of International and Comparative Law, 2017, 207.

128 Lietuvos Respublikos Vartotojų teisių gynimo įstatymas 12. cikk. 
és mind a polgári, mind a közigazgatási eljárási szabályok alapján benyújtható a kereset. $^{129}$

\subsection{A fellépésre jogosultak}

A litván polgári perrendtartásban nincsenek meghatározva azok a közérdekvédelmi területek, amelyek körében fellépésre van lehetőség, ezért a vonatkozó jogszabályi rendelkezéseket a bírói gyakorlat úgy értelmezi, hogy csoportos keresetet olyan személyek nyújthatnak be, akiknek a közérdek védelmében történő fellépése jogszabály által megengedett. A csoportos kereset kapcsán a törvény nem tartalmaz kizáró rendelkezést arra vonatkozóan, hogy kinek van joga közérdekű igényérvényesítésre, de nem tartalmaz pozitív listát sem. Továbbá nem határozza meg sem a csoport tagjainak minimális létszámát, sem pedig a csoportot képviselőkkel kapcsolatos kritériumokat. A csoportban való részvétel kapcsán ugyancsak hiányos a szabályozás. A perrendtartás általános rendelkezései alapján az ítélet hatálya csak ügyben részt vevő személyekre vonatkozhat, következésképpen a perrendtartás közvetetten az opt-in eljárásra ad lehetőséget. ${ }^{130}$ Az összes többi kollektív fellépési mechanizmus esetén meghatározott a fellépésre jogosultak köre. A közérdek védelmére irányuló általános keresetet az ügyész, az állam, önkormányzat vagy külön törvény által a közérdek védelmére kijelölt más személy nyújthat be. ${ }^{131}$ Abban az esetben, ha jogszabály nem ruház fel senkit kereshetőségi joggal, keresetet az ügyész akkor is benyújthat a társadalom vagy az állam jogszabály által védett érdekeinek védelmében. ${ }^{132}$ Mindezeken túl a két közérdek védelmében történő igényérvényesítés esetén a perindítóknak a közérdek fennállását kell bizonyítaniuk. ${ }^{133}$ Figyelemre méltó megoldás a litván jogban, hogy a közérdek védelme olyan hangsúlyt kap, hogy az általános bizonyítási szabályokkal ellentétben, a közérdekű ügyekben a bíróság aktív szerepet is vállalhat, hivatalból is jogosult a bizonyítékok összegyűjtésére. ${ }^{134}$

Ágazati fogyasztóvédelmi kollektív fellépéssel az Állami Fogyasztóvédelmi Hatóság, a fogyasztói egyesületek törvényben meghatározott esetekben, más állami és önkormányzati intézmények és civil szervezetek élhetnek. ${ }^{135} \mathrm{Az}$ állami és önkormányzati szervek csak törvényben meghatározott esetekben léphetnek fel. A civil szervezetek kapcsán feltétel, hogy alapszabályban foglalt céljuk a fogyasztók védelme, valamint legalább húsz taggal kell rendelkezniük. ${ }^{136}$ Versenyjogi kollektív keresetet a vállalkozások vagy a fogyasztók érdekeit képviselő szervezetek indíthatnak. Ezeknek bizonyítaniuk kell a bíróság előtt azt is, hogy jogosultak a vállalkozások vagy a fogyasztók érdekeinek képviseletére. Végezetül környezetvédelmi jogi kol-

\footnotetext{
129 Mizaras: i. m.

130 Civilinio Proceso Kodekso 266. cikk.

131 Civilinio Proceso Kodekso 49. cikk.

132 Bubliene-Mizaras: i. m., 207.

133 MizARAS: i. $m$.

134 Civilinio Proceso Kodekso 178. cikk.

135 DeVroe: i. m., 156.

136 Lietuvos Respublikos Vartotojų teisių gynimo įstatymas 30. cikk.
} 
lektív igényérvényesítéssel arra jogosult egyesületek és közjogi szervek élhetnek. Az egyesületek akkor jogosultak a keresetindításra, ha bizonyítják, hogy a céljuk a környezet védelme, és a szervezet létrejötte még a kifogásolt döntés megszületése előtt megtörtént. ${ }^{137}$

\subsection{A fellépések a gyakorlatban}

A gyakorlatban a két igényérvényesítési típus közül egyedül a közérdek általános védelme érdekében indítható közérdekü keresetet alkalmazzák. ${ }^{138} \mathrm{~A}$ csoportos fellépés hiányának dogmatikai oka van, ugyanis a perrendtartás semmilyen különös szabályt nem ír elő a csoportos igényérvényesítés kapcsán. A Litván Fellebbviteli Bíróság (Lietvuvos Apeliacinis Teismas) álláspontja szerint a szabályozás hiányossága miatt csoportos perindításra a litván jogban gyakorlatilag nincs mód. ${ }^{139}$ Ezért a gyakorlatban inkább az azonos kérelmek egyesített elbírálását alkalmazzák az általános eljárásjogi rendelkezések alapján. ${ }^{140}$

Ezzel szemben a közérdek védelmét célzó általános igényérvényesítést igen széles körben és gyakran alkalmazzák. Litvániában nagyon sikeres kollektív jogintézménynek tekinthető. Különösen a tisztességtelen szerződési feltételek kapcsán az Állami Fogyasztóvédelmi Hatóság aktív, 2011-ben 53 ügyben, míg 2012-ben 127 ügyben járt el. Határon átnyúló jogsértések esetén viszont nem indult eljárás. A versenyjogi kollektív fellépéssel a gyakorlatban nem élnek. A környezetvédelmi igényérvényesítésre kevés számban kerül sor, inkább a közigazgatási szervek által hozott rendelkezések vagy közigazgatási aktusok miatt fordulnak elö, többnyire a településrendezési ügyekben. ${ }^{141}$

\section{Következtetések}

A bemutatott országok példáin keresztül jól látható, hogy a kollektív igényérvényesítési mechanizmusok bevezetése társadalmi-gazdasági szükségletből ered. A társult perlési mechanizmusokat jellemzően a fogyasztókat nagyobb körben érintő károkozásokkal szembeni hatékonyabb fellépés elősegítése érdekében alkalmazzák, a felek közötti egyenlőtlenségeket hivatottak kiküszöbölni (Ausztria, Olaszország, Franciaország). Ezek alapvetően fogyasztóvédelmi, illetve a versenyjogi érdekeket védő jogintézmények. ${ }^{142} \mathrm{Az}$ alanyi joggal rendelkező személyek állnak perben, nagyobb erőt képviselve az összeadódó kárigények nagysága miatt, mintha

137 Mizaras: i. $m$.

138 2003-tól 2013-ig csak két ügy indult.

139 Lietvuvos Apeliacinis Teismas, 2009-06-02 order No 2-492/2009.

140 Bubliene-Mizaras: i. m., 208.

141 MIZARAS: i. $m$.

142 Hensler, Deborah R.: The Global landscape of collective litigation. In: Hensler, Deborah R.-Hodges, Christopher-Tzankova, lanika: Class Actions in context - How Culture, Economics and Politics Shape Collective Litigation. Edward Elgar, Cheltenham UK, Northampton, MA, USA, 2016, 3. 
egyénileg léptek volna fel. A részvétel az anyagi jogosult szubjektív döntésének eredménye, ${ }^{143}$ a perrel elérhető hasznok arányosságának mérlegelésén alapul. A gyakorlati tapasztalatok azt mutatják, hogy a csoporttagság szabályozása visszahat a mechanizmus eredményességére. Az opt-in rendszer az elterjedtebb az Európai Unió tagállamaiban (ezzel szemben Hollandia, Portugália és Dánia az opt-out rendszert vezette be). ${ }^{144} \mathrm{Az}$ opt-in rendszerben a csoporttagok alacsony részvételi aránya - például a megfelelő tájékoztatásának hiánya miatt (például Olaszország) - jelentősen rontja a jogintézmény hatékonyságát. ${ }^{145} \mathrm{Ez}$ azzal a veszéllyel jár, hogy ha az érintettek viszonylag kevés része kerül kártalanításra, a jogsértő vállalkozás tovább folytathatja tevékenységét. ${ }^{146}$ Ezzel szemben az opt-out valódi visszatartó hatással járhat, mivel a vállalkozás kénytelen valamennyi károsultat kártalanítani. Az eljárások sikerességét nem befolyásolja, hogy a csoportot az egyik alanyi jogosult képviseli (Olaszország) vagy egy külön képviselő (Franciaország, Ausztria). Az optout rendszerek előnyeit rendszerint a hatékonysággal és a későbbi jogsértésektől elrettentő hatásával szokták igazolni. Különösen igaz ez a csekély perértékű ügyekben, ahol kicsi a perlési hajlandóság. ${ }^{147}$

A kollektív igények érvényesítésének másik ága elválik az egyéni érdekektől, nem a tárgyi jog által elismert alanyi jogok biztosítására szolgál. A célja, hogy olyan, a jogértésekkel szemben is megfelelő magánjogi válasz álljon rendelkezésre, amelyekkel szemben közvetlen egyéni érintettség hiányában vagy az érdekérvényesítés gyenge pozíciója miatt valószínűsíthetően nem kerülne sor fellépésre (esélyegyenlőség, környezetvédelem, egészségügy, adatvédelem, munkavállalók védelme, befektetők védelme, fogyasztóvédelem). Ezek az eljárások - eltérően a társult perléstől - szükségszerüen nem az okozott kár megtérítését célozzák. Jellegükből következően a jogsértés megállapítására, megszüntetésére, a további jogsértéstől való eltiltásra irányulnak, mint Litvániában, Portugáliában és Franciaországban. Persze nem kizárt az sem, hogy egyben lehetőség szerint az okozott egyéni károk is orvoslásra kerüljenek, de ahogy láthattuk, ez utóbbi a közérdekü feljogosításoknak nem meghatározó eleme. Ennek ellenére közvetett módon nagyon is hatékonyan segítik az egyéni igényérvényesítést, mivel a közérdekü perben megállapított felelősségre alapozva az egyes fogyasztók külön perben jó eséllyel igényelhetnek kártérítést (ezt támasztották alá a portugál, litván és osztrák példák), vagy vegyes rendszert alkalmazva a kollektív érdekek érvényesítése érdekében történő fellépés során kártérítési kötelezettség megállapítása is kérhető, mint a francia megoldásnál. Ez kompenzálja a gyengébb pozíciójú fogyasztók oldalán felmerülő (információs, pénzügyi, érdekérvényesítési) aszimmetriát, ${ }^{148}$ és csökkentheti azt a terhet is, ami az egyéni perlések folytán a bíróságokra hárulnának.

143 JóJÁRT: i. m., 1209.

144 Muhleron, Rachael: The Case for an Opt-Out Class Action for European Member States: A Legal and Empirical Analysis. Columbia Journal of European Law (2009), 15, 409.

145 BERHG: i. m., 12.

146 Trstenjak, Verica-WeingerL, Petra: Collective Actions in the European Union - American or European Model? Beijing Law Review, 2014/5, 156.

147 HARSÁGI (2015): i. m., 224.

148 TrstenjaK-WeingerL: i. m., 156. 
A fellépések gyakorlati tapasztalataiból látszik, hogy az eljárás kezdeményezésére jogosultak körének meghatározása a jogintézmények hatékonyságában jelentős különbségeket okozhat. Az állami hivatalok rendszerint információelőnnyel rendelkeznek, és hatékonyabban képesek orvosolni a társadalmi érdeksérelmeket magán fellépésének hiányában is. ${ }^{149} \mathrm{Az}$ állami szervek feladata törvényben elöírt, és ennek érvényesülését biztosítja az állam személyi és finanszírozási háttere. Az állami szervek képesek megfelelő létszámú és szaktudású munkaerő folyamatos alkalmazására, és a perléssel járó költségek nem jelentenek olyan kockázati tényezőt, amelyek megakadályozhatják a fellépést. Ez különösen a kevésbé fejlett civil szférával rendelkező államokban meghatározó körülmény (mint például Portugáliában). A civil szervezeteknél - mindamellett, hogy szerepük nagyon jelentős - a finanszírozás megoldása kulcskérdés, hiszen még pernyertesség esetén is a várható előny nagysága is elmaradhat a szükséges ráfordítástól. ${ }^{150} \mathrm{~A}$ magas költségek miatt a pénzügyi háttér hiánya akár a jogsértő magatartással szembeni fellépés elmaradásához is vezethet, figyelemmel arra a tényre is, hogy Európában a „vesztes fizet” elve jellemző a polgári eljárásjogokban. ${ }^{151}$ Ezt orvosolandó pragmatikus megoldást nyújt a portugál gyakorlat, ahol a civil szervezetek a feltárt ügyeket a szintén fellépésre jogosult ügyészséghez irányítják.

A bemutatott példákból leszürhető következtetés alapján az állami támogatásban részesülö, valamint a tömeges tagságuk révén önfinanszírozható szervezetek képesek a perindításra (Ausztria, Franciaország). Tehát a tökeerős tömegszervezetek, de különösen állami beavatkozás nélkül a társadalmi érdekek védelme nem lehet biztositott. Ez különösen érzékelhető a határokon átnyúló jogsértések kapcsán. A költségek rendkívül megnőnek a külföldi elemet tartalmazó eljárásokban. A fordítási, utazási költségek, a külföldi jogot ismerö ügyvéd dijjazása láthatóan olyan anyagi terheket és kockázatot jelent, amely miatt a vizsgált országokban szinte egyáltalán nem indítanak ilyen eljárásokat, még az óriási tagsággal rendelkező szervezetek sem. A költségek viselése a társult perlési mechanizmusok kapcsán is meghatározó szempont, hiszen jelentős hatása van azon hajlandóságra, hogy képviseljék-e a csoportot.

A fellépési jogosultság és a finanszírozási kérdése mellett a kollektív mechanizmusok sikerességében nagy felelössége van a jogalkotóknak is. Ugyanis az elemzett példákból az is látszik, hogy az anyagi jogi és eljárásjogi szabályok által gördített nehézségek szintén befolyásolják a fellépési hajlandóságot. A litván csoportos közérdekű perindítás a szabályozás hiányosság miatt a gyakorlatban nem létezik. Ausztriában pedig a csoportos igényérvényesítés hiányát az „osztrák stílusú class action" a polgári perjog célirányos értelmezésével tölti ki. Az államok eltérő eljárásjogi rendszerei pedig a határon átnyúló jogsértések tekintetében lényegében leküzdhetetlen akadályt jelentenek. Ez utóbbi különösen jelentős problémát jelenthet a jövőben, különösen a határokat átívelő internetes kereskedelem rohamos térnyerése

149 BerHG: i. M., 12.

150 TZakas, Dimitrios-Panagiotis: Effective Collective Redress in Antitrust and Consumer Protection Matters: A Panacea or a Chimera? Common Market Law Review, 2011/4, 1125.

151 Hodges, Cristopher: Collective Redress in Europe: The New Model. Civil Justice Quarterly, 2010/24, 370. 
miatt. Az igazságszolgáltatáshoz való hozzáférés ezért az Európai Unió fogyasztóvédelmének egyik legnagyobb kihívásává válhat. ${ }^{152}$

\section{Abstract}

Collective redress mechanisms can be seen in almost all of European countries (except Switzerland and Czech Republic for example). The established regulatory solutions are diverse, basically two lines are typical, and mixed systems based on these are created. One is a representative collective claim enforceable to protect the collective interests of the community (public interest). In general, such claims can only be enforced by government bodies designated by a legislator or by associations whose purpose is the protection of those interests. Another type of collective demand assists the homogeneous demands of a group of individuals by taking advantage of the merged action. In these cases, a person is usually validated by the requirements of the group members, who is himself interested in the proceedings because of his own material right.

152 BenÖHR, Iris: Consumer Dispute Resolution after the Lisbon Treaty: Collective Actions and Alternative Procedures. Journal of Consumer Policy, 2013/1, 87-110. 